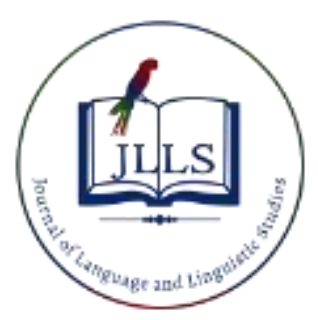

Available online at www.jlls.org

JOURNAL OF LANGUAGE AND LINGUISTIC STUDIES

ISSN: $1305-578 \mathrm{X}$

Journal of Language and Linguistic Studies, 16(2), 1019-1031; 2020

\title{
Reflection or description: A document analysis on ELT student teachers' reflective journals
}

\author{
Gülden İlin 1 (iD

\section{APA Citation:} \\ Çukurova University, Adana, Turkey \\ Ilin, G. (2020). Reflection or description: A document analysis on ELT student teachers' reflective journals. Journal of Language and Linguistic \\ Studies, 16(2), 1019-1031. \\ Submission Date: $28 / 04 / 2020$ \\ Acceptance Date:23/05/2020
}

\begin{abstract}
This documentary study analyses the levels of reflection in the reflective journals written by 59 ELT student teachers from a Turkish university upon their experiences at practice schools. During the practicum, each student teacher wrote four reflective journals on pre-determined topics for observation. The foci of journals were on the lesson observed, the mentor's classroom management strategies, classroom context and language, blackboard use and error correction. In this study, the journals were analyzed on the basis of Hattan and Smith's (1995) reflective writing styles and categorized under reflective models by Taggart and Wilson (2005). The analysis reveals that student teachers used a descriptive tone in writing their journals rather than a reflective one. The majority of the reflective statements used were in technical level followed by contextual level. In the journals, as compared to descriptions and reflections in technical and contextual levels, we detect rarer reflections in dialectical level. To shed more light to the study, interviews were held with eleven student teachers selected by convenience sampling method and the results of the analysis were discussed. Not being familiar with the word reflection, time constraint, lack of motivation, the nature of tasks and finally, distrust in the probability of supervisors' reading the journals were the reasons why the student teachers did not much care about how they wrote the journals.
\end{abstract}

(C) 2020 JLLS and the Authors - Published by JLLS.

Keywords: ELT teacher education; reflection; document analysis; reflective journals; teaching practice

\section{Introduction}

\subsection{Literature review}

Teacher reflection continues to be an inseparable part of teacher education. When we go through the related literature, we find a variety of definitions for the term. For example, Boyd and Fales (1983) views reflection as a process of creating and clarifying the meanings of experiences in terms of self in relation to both self and the world. As they discuss, the outcome of this process is "changed conceptual perspectives." Similarly, reflection is a highly valued way of thinking and reflecting is an important part of professional practice (Schön, 1983 in Farr, 2012 p. 11), of learning (Kolb, 1984 in Healey and Jenkins, 2007 p. 185), and a means for metacognitive development (Vos, 2001). Without reflection, learning ends "well short of the re-organization of thinking that 'deep' learning requires" and reflecting on

\footnotetext{
1 Corresponding author. Tel.: +90-322-338-6084/2793

E-mail address: guldenilin@cu.edu.tr
} 
teaching is a way to make teachers aware of how they teach. It is a method for self-assessment (Ewell, 1997).

In a similar vein, Dewey (1933) identifies reflection as one of the modes of thought: "active, persistent, and careful consideration of any belief or supposed form of knowledge in light of the grounds that support it and the future conclusions to which it tends" (p. 7). He views it as a further dimension of thought, and as such in need of education; he suggests that while we cannot learn or be taught to think, we do have to learn to think well, especially acquire the general habit of reflection. Teachers' reflective thinking tools such as recording, writing, drawing, photography, learning journal, portfolio, lesson plan, co-teaching, collaborative practitioner enquiry and action research can be used to support teachers' reflective thinking skills (Dymoke \& Harrison, 2008 in Mirzahi, Phang \& Kashefi 2014, p. 640).

One of these supporting tools that trigger reflection is reflective journals which are frequently used in teacher education programs. Hattan and Smith (1995) define four levels of reflective writing in student teacher journals. The first one is descriptive writing. In this level, the writer shows no attempt to provide rationale or take issue with an event. Thus, it cannot be considered as reflection. In the second level, that is descriptive reflection, justification is made in addition to description often based on personal experiences. In dialogic reflection which is written in the third person with judgements, we observe exploration of reasoning, and recognition of multiple perspectives. Finally, in the critical reflection level, the writers respond to episodes by relating to the influence of multiple historical and socio-political aspects. In addition, they write about reflection types. As Hattan and Smith put forth, the first one is technical reflection in which teachers think about decision making about immediate behaviors or skills. Descriptive reflection is the act of analyzing one's performance in the professional role and giving reasons for the actions taken. The third level is dialogic reflection during which people are involved in processes for evaluation of observed instances in stimulated recall interviews exploring alternative ways to solve problems in a professional situation. Finally, in critical reflection level, teachers think about the effects of their actions upon others of one's actions, taking account of social, political and/or cultural forces" (p. 45). Parallel with Hattan and Smith, Taggart and Wilson, (2005) suggest that there are three models or levels of reflection: these are technical level, contextual level and dialectical level. In technical level the focus is on methodological problems and theory development to achieve objectives. In contextual level clarification of and elaboration on underlying predispositions of classroom practice and consequences of strategies are questioned. Lastly, in dialectical level, people are involved in questioning processing of moral and ethical issues related directly and indirectly to teaching practice.

Similarly, in a heuristic manner Frederick and Sadler (2013) describe and interpret the reflection in two dimensions: orientations to and components of reflection. The orientation dimension considers the increasing complexity of reflective thought through five levels: technical, reflection-in and on-action, deliberative, personalistic, and critical. As they put forth, the components dimension describes how teacher educators operationalize and implement reflective practice in the curriculum of teacher education courses. They write about four components. These are the stimuli, content, process, and outcome. These two dimensions are organized into a heuristic that contains descriptors for each confluence of components and orientations. This heuristic is useful in identifying and understanding the conceptions of and intentions for reflection by teacher educators (p.1).

On the other hand, from a critical perspective, Kurt (2017) argues that these levels do not have a clear cut pattern and that reflective thinking needs to be better comprehended by the teacher trainer in order to be effectively implemented and exercised in the process of thinking and learning. Thus, he proposes a new framework for reflective acts. In his framework, the first step is meta-analysis which serves to locating statements containing learner reflections followed by identifying learner reflective statement in the text as the second step. Next, purport analysis which deals with determining the purport 
of the reflection and then fourthly converting reflections into a specific reflective act follows. The fifth step is to do with converting the specific reflective act into a common reflective act and then intention analysis in other words determining the intention of the reflective act and finally classification, that is, subsuming particulars into the general follow (p.5).

Parallel to Kurt, Yuan and Lee, (2014) emphasize the importance of a deeper understanding of the meaning and level of reflection by the teacher trainers. As they indicate, for example practicum may not be as effective as supposed to be due to lack of practical guidance in and understanding of reflective processes as it has a transformational nature to change beliefs where metacognition is involved at a deeper level than probably any other thinking process. In addition, critical reflection has been recommended as a means of incorporating issues of equity and social justice into teaching thinking and practice. It may serve to creating culturally relevant teaching strategies and the development of such strategies is contingent upon critical reflection (Howard, 2003, p.197). In the same vein, Larrivee (2008) suggests that reflection goes beyond critical inquiry by adding to conscious consideration the dimensions of deep examination of personal values and beliefs, embodied in the assumptions teachers make and the expectations they have for students (p. 341). As she argues, unless teachers develop the practice of critical reflection, they stay trapped in unexamined judgments, interpretations, assumptions, and expectations Larrivee (2000). Thus, as she propounds there is the need for a commonly shared language to categorize the various levels involved in becoming a critically reflective teacher. In addition, Nelson and Sadler (2013) write that various texts generated by pre-service teachers such as journals, portfolios, or interviews are analyzed with the goal of characterizing reflective thinking into various levels of development, but warn that the experiences that facilitate development should not be ignored. Similarly, Dewey (1933) points us in the direction of building upon the experience of the learner. Finally, Boud \& Miller (1996) places experience in the central place in learning, and underline the learners' need to construct their own experience in the context of their own past and present, as well as the wider social and cultural context of their learning (in Martin, 2005 p. 526).

\subsection{Research questions}

On the basis of the above views, agreeing that practice can only be improved in contexts in which it normally occurs (Hopkins, 2005) and that there is a general agreement that the practicum is a key aspect of a teacher education program (Glickman \& Bey, 1990; McIntyre, Byrd, \& Fox, 1996 in Beck \& Kosnik, 2002 p. 81), investigating the student teachers' reflection levels during practicum seems to be worthwhile. Such an effort may also deserve attention in that the procedure may help to enhance teacher trainers' meaning making and understanding of sounder assessment means as well as more formative guidance for prospective teachers. Therefore, the research questions for this study have been formed as follows:

1. Do ELT student teachers really reflect on their practicum experiences in their reflective journals?

2. What are the most frequently used reflective models in the student teachers' journals?

3. How do they comment on the study outcomes?

\section{Method}

In this part, data collection and analysis procedures used for the study are presented. The ways utilized to maintain the trustworthiness of the study are also explained. 


\subsection{Data collection procedures}

Document analysis is a form of qualitative research in which documents are interpreted by the researcher to give voice and meaning around an assessment topic (Bowen, 2009). In this documentary analysis, the levels of reflection in the reflective journals written by 59 ELT student teachers from a Turkish university upon their experiences at practice schools are investigated. During the practicum, each student teacher wrote four reflective journals on pre-determined topics for observation. The foci of journals were on the lesson they observed, the mentor's classroom management strategies, classroom context and language used, and finally blackboard use and error correction.

Mayring (2014) identifies the pros and cons of qualitative and quantitative research designs as well as mixed methodologies. He reports that some advocates of Grounded Theory demand not to block the open sight on the subject by theories. However, as he discusses every research process is somehow influenced by (hidden or formulated) preconceptions and only by linking research to theory a scientific progress is possible (p11). Likewise, in this study, the journals were analyzed on the basis of Hattan and Smith's (1995) reflective writing styles and then matched and categorized under reflective models in Taggart \& Wilson 2005, p.3) as in this model the levels are more concisely defined. As Bowen also warns, "A document may not perfectly provide all the necessary information required to answer the research questions. Some documents may only provide a small amount of useful data or sometimes none at all. Other documents may be incomplete, or their data may be inaccurate or inconsistent. Sometimes, there are gaps or sparseness of documents, leading to more searching or reliance on additional documents than planned" (p.1). Thus, to shed more light to the study, semi structured interviews were held with eleven student teachers selected by convenience sampling method and the results of the document analysis were discussed.

\subsection{Data analysis}

This documentary study analyses the levels of reflection in the reflective journals written by 59 ELT student teachers from a Turkish university upon their experiences at practice schools. The student teachers wrote four pages in average and each page contained between 11 to 14 sentences which means there were approximately 236 pages and about 2700 to 3000 sentences in total that were analyzed. The selection of papers was made randomly among the journals written by student teachers from different practice schools and the writers gave their consent for the study. Their names were kept confidential and the journals were not used for any other purposes than the present study nor shared with any other parties.

In order to analyze the journals, as the first step they were grouped according to their topics. Journals for each topic were analyzed separately on a three phase coding procedure. In the first coding phase, student journals were read and codes were given to sentences as 'description' and 'reflection'. Having completed this labelling process, as the second phase of data analysis, the reflective sentences were marked with appropriate levels of reflection on the basis of Hattan and Smith's (1995) reflective writing styles. Finally, in the third phase identified writing levels were matched with Taggart and Wilson's (2005) reflective models. Frequencies of each model were calculated separately for each of the topics investigated in the study. On the other hand, interview data were subjected to content analysis.

\subsection{Trustworthiness}

Trustworthiness in both procedures was maintained by means of reproducibility. That is, the procedures were determined by two coders prior to the analysis. After the analysis was completed by the coders individually, the codes and categories that emerged were matched. Labelling and relabeling 
continued until the two coders' consensus on the codes and categories was attained (Elo and Kygnas, 2008).

\section{Results and Discussions}

In this part, the results obtained in the study are discussed separately in the order and on the basis of each observation task used during the practicum. These are the lesson observed, the mentor's classroom management, the context and the language used in the classroom and finally blackboard use and error correction.

\subsection{The lesson observed}

The first topic in the student teachers' reflective journals was about the lesson they observed. According to the Hattan and Smith's (1995) categorization of writing levels, we find that most of the sentences the student teachers wrote in their journals about this topic remained at description level (401sentences). The sentences such as "Teacher revised the previous lesson", "Teacher used elicitation techniques" or "Teacher presented the new topic" constituted the larger part of the journals. They wrote sentences like "Teacher followed the course-book", "Teacher used silent reading / read aloud techniques" or "Teacher asked follow up /procedural /display /recall questions" and "Teacher did the dialogue part with the students." However, they made no comments or never added their views to the teaching techniques. Thus, what they wrote appeared rather like a chronological summary of the observed lesson.

Table 1. Lesson observed

\begin{tabular}{ll}
\hline Sentences & Fr. \\
\hline Description & 401 \\
Technical & 173 \\
Contextual & 133 \\
Dialectical & 0 \\
\hline
\end{tabular}

In technical level, we encounter 173 sentences for this topic. In technical level, we find reference to past experiences, teacher competency towards meeting outcomes, focus on content, reference to past experiences, behavior and skill, and simple theoretical descriptions. This level corresponds to descriptive reflection level in writing. The following may be given as examples for sentences written in this level:

"Teacher focused on memorizing most probably because she was not prepared for the lesson. If she were prepared, she could have conducted a more communicative lesson. What I learnt out of this lesson is that, especially as an inexperienced teacher, I should do my best to make myself prepared for my lesson by all means." (behavior and skill)

We find in this sentence that the student teacher is commenting on the lesson on the basis of the observed teacher's behavior and skill and she develops an understanding of what is good for her in the future as a teacher in her class. This sentence closely coincides with Boyd and Fales (1983) definition of reflection as a process of creating and clarifying the meanings of experiences in terms of self in relation to both self and the world.

In the following excerpt, the writer evaluates the lesson: 
"Teacher paraphrased the question until students finally understood. This is an effective way as far as I remember from my methods course." (reference to past experiences)

Similarly, the sentence below is also a reference to past experiences:

"While the time for the activity was about to be over, teacher signaled the remaining time. This is a good thing to do. We did the same in our micro teaching sessions at the department."

Regarding contextual level, we find 133 sentences. In contextual level, we encounter alternative practices, choices based on knowledge and value commitments, content related to context, student needs, analysis, clarification and validation of principles which corresponds to dialogic reflection in Hattan and Smith's categorization. In the following two excerpts, the student teachers criticize the mentor and they propose alternative ways to do the things instead of what the teachers did.

"The teacher did not at all use extra materials but strictly adhered to the course book. I know that this is not the right thing to do. As a teacher she must have assessed students' performances, identified their needs and prepared extra materials. She must have done this to save time and effort." (alternative practices, student needs and choices based on knowledge)

"Teacher read the text aloud and asked comprehension questions. This is not appropriate. Students cannot understand the text this way." (choices based on knowledge, student needs)

In the reflective journals, concerning the lesson observed student teachers produced sentences at technical and contextual levels. However, we find no statements to be categorized under dialectical level.

\subsection{Classroom management}

The second topic the student teachers wrote journals on was about the mentors' ways of managing the classroom. Similar to the first topic, we find that student teachers wrote more descriptions (343 sentences) than reflections (135 sentences in total) in their journals. As for the examples for descriptions, we may give the following sentences: "Teacher used group /pair work activities." "Teacher said "be quiet please." "Teacher maintained eye contact with the students." "Teacher used body language to maintain class order." Similar to the ones in the journals written for the first topic, the lesson observed, the sentences followed one another such as a list of happenings that took place in the lesson.

As displayed in the table as well, the sentences written in the reflective mode are found to fall only in technical (121 sentences) and, at a much lower frequency, at contextual level (14 sentences).

Table 2. Classroom management

\begin{tabular}{ll}
\hline Sentences & Fr. \\
\hline Description & 343 \\
Technical & 121 \\
Contextual & 14 \\
Dialectical & 0 \\
\hline
\end{tabular}

Below, we see how a student teacher elaborates on one of the problematic sides of the mentor's classroom management strategies.

"The role of the teacher is a guide for students in student centered classes, this makes the classroom management much easier." (simple theoretical description)

In the contextual level, though not frequently, we observe a variety in the reflective comments. In the examples, the student teachers refer to alternative practices, to their knowledge about teaching, 
taking into consideration of student needs and reflecting about their own principles among others. The examples below serve to elaborate on each issue.

"The mentor taught the lesson by lecturing. Instead, she should have used posters, visuals, flashcards, authentic materials puzzles, songs, and strategies for peripheral learning. If you do not use these alternative ways, this means that you are ignoring the students' characteristics and needs. As a consequence, students will not fully benefit from the lesson." (alternative practices, student needs, analysis)

"I know that classroom management is related with a variety of factors. Things could have been much easier if the teacher had started the lesson with a short friendly conversation with students and created a warm classroom climate." (choices based on knowledge)

"If teachers do not use enjoyable activities at this age level, the students will be demotivated and managing the class will be difficult." (student needs)

Excerpt: Teacher sticks a plan on the wall and when they finish each one of them, she puts a tick. I have to think about this. I can't make my mind up on whether this is something good to do or not. Or whether it serves to any kind of a purpose. (validation of principles)

On the other hand, we do not come across sentences that go under dialectical level in reflective journals about classroom management.

\subsection{The context and language}

The following topic about which the student teachers were expected to reflect upon on the basis of their observations at the practice school was "the context and the language." Contrary to what we found in the journals written for the previous two topics, student teachers produced sentences that go under all three categories of reflective levels (524 sentences). However, when we consider the number of sentences used for each level we once again observe that they produced more sentences that go under the description category. (392 sentences)

Table 3. Context and language

\begin{tabular}{ll}
\hline Sentences & Fr. \\
\hline Description & 392 \\
Technical & 256 \\
Contextual & 215 \\
Dialectical & 53 \\
\hline
\end{tabular}

As regards to descriptive sentences, the student teachers wrote that "the classroom was crowded and noisy" or "the teacher used instructions in mother tongue" and "very seldom used the target language." There were sentences that revealed their puzzlement before the mentor's behavior: "my mentor uses the mother tongue even for question and answer activities but when the students say something in mother tongue she warns them and demand that they say it in English."

Sentences at technical level were the most frequently observed in this topic as compared to the others. They refer to past experiences at the department and they direct their attention by far on the mentors' behaviors although their focus for the weekly observation is the context and the language. The following may make an illuminating example:

"My mentor sometimes switched to the mother tongue. This, as we discussed in our methods courses, is not a bad thing to do. But, we have to be monitoring our language and refrain from excessive 
use of mother tongue. Sometimes this is unfortunately what our mentor does." (past experiences, focus on behavior)

At contextual level, student teachers disapprove their mentor's insufficient use of target language. However, unlike the sentences used at technical level we find guiding ideas to better the existing situation as seen in the following excerpt:

"Teacher uses English only when she is reading something from the book. We cannot expect students learn or speak the language in this way. Maybe because of this, the students are not at all interested and bothered to participate in activities. This is not fair on behalf of the students. Teachers should consider the students' needs and expectations from the course before they make their decisions." (student needs, choices based on knowledge and value commitments)

Regarding this topic, the student teachers wrote 53 sentences in dialectical level. In this level, people are involved in questioning processing of moral and ethical issues related directly and indirectly to teaching practice which corresponds to critical reflection in Hattan and Smith's (1995) levels. In the excerpts, we see that student teachers referred to moral ethical and socio political issues in their journals:

"During the lessons students chat, walk and change their desks and provoke each other. Then teacher gets angry and shouts at them and scolds them. Unfortunately, it appears that the students have long ago become inured to such behaviors, they ignore the teacher. This is a shame for both parties. Teachers are also expected to make good models by all means and teach students appropriate manners as well as languages in our case." (moral and ethical issues)

Another excerpt sheds light on how the student teacher analyses the mentor's psychological state and puts forth some solutions to create a better context for all teachers:

"... Most probably all these unpleasant events we witness in the classroom stem from the fact that the teacher is not content with her job. I believe that teacher wages, school facilities, even the course books may all need to be reconsidered by MONE and teachers should be involved in a process of change. Their views should be listened to. Teachers deserve more respect and feeling of valuableness." (moral and ethical, socio political issues)

\subsection{Blackboard use and error correction}

The final topic to be observed in the mentors' classes was blackboard use and error correction techniques. In the journals, we find that the student teachers produced reflective sentences at all three levels (554 sentences in total) besides descriptions. (377 sentences)

Table 4. Blackboard use and error correction

\begin{tabular}{ll}
\hline Sentences & Fr. \\
\hline Description & 377 \\
Technical & 244 \\
Contextual & 263 \\
Dialectical & 47 \\
\hline
\end{tabular}

Sentences that described the happenings in the classes for the week's observation task were like the following:

"Teacher wrote the questions on the board," "Teacher divided the board into two and wrote the unknown vocabulary items on to the right," "Teacher corrected students' mistakes immediately," or "Pairs of students corrected each other's' sentences." 
For this task, we see that student teachers used statements at technical level and used some simple theoretical descriptions or referred to their past experiences at the department such as:

"According to the articles I read in the courses, the teacher should have called the students to the board. This way, they would both have the chance to decharge their energy and feel a part of the lesson which is very important at this age level. This is linked with the attitude goals." (simple theoretical description)

"The teacher should have been more careful with her handwriting. During our microteaching sessions, our lecturer always warned us about that." (reference to past experiences)

As for the reflections in contextual level, student teachers mostly referred to student needs and alternative practices as below:

"Our mentor is very talented. She drew simple pictures on the board and told a story to the students. In fact, people at all ages like listening to stories. Watching the teacher draw these pictures was fun even for me put aside the children. In the future by practicing, I may improve my ability to draw and address a variety of student profiles. I think the teacher should also have involved the students in this drawing process. It would have been much fun. This is what we learnt in our young learners course." (student needs, alternative practices, past experiences)

At dialectical level, student teachers reflected on moral and ethical issues such as the consequences of rewarding or punishing the students and messages we may give unconsciously to our students through the language we use or our manners as teachers, the materials and examples we bring to the classroom environment among many other things. The following two excerpts from the journals are the examples for such comments:

"Teacher used rewards and punishment for mistakes. This will have a negative consequence on students' understanding of mistakes and studying their lessons. As a matter of fact, the teacher gave a subliminal message that something should be given to students as a reward when they achieve something. In fact, they study and achieve things for themselves. The students should learn this message. I am not even talking about punishment. This is out of question." (moral ethical issues)

"Teacher was angry with the students and so she gave minuses and extra homework to them. It's a shame and humiliating for the students. In addition, the students will start to think that homework is a kind of punishment. I think that the teacher should approach the students with a more humanistic manner and try to develop an understanding toward her students. They are younger and think differently from the teacher. I think first of all we should try to establish a rapport and make sure that we respect our students." (moral ethical issues, self-understanding)

\subsection{Student teachers' interpretations of study results}

When asked about their comments on the study outcomes during the interviews held with 11 student teachers, we find that the student teachers heard the word reflection for many times and completed reflective work as part of the requirements of various courses at the department. However, according to their interpretation they had not fully grasped the meaning of reflection. They thought that writing about what they observed in detail would suffice ( 9 students).

Second, during the practicum the student teachers go through a hectic period. They try to catch up with the courses at the department, take exams, complete assignments, prepare presentations for various courses, observe classes, fulfill the requirements of the practicum, and devote time to prepare themselves for the recruitment exam (KPSS) among many other responsibilities they have to bear on their shoulders in the last year of their education. Thus, even if they already have developed an understanding of what was actually expected from them in terms of the reflective journals, they did not want to devote time 
and put extra effort to thinking that deeply on what to write when they have such other things to do (8 students).

In addition, the observations in the practice schools partially disappointed them as they did not have the chance to observe some of the task topics in the classroom. Thus, they lost their motivation for reflection. For example, as the student teachers underlined, for some of the observation tasks such as mentor's instruction giving or use of presentation practice production phases of the lesson, in some cases it was not possible for them to collect observational data and reflect upon them within the contexts of practicum. According to the student teachers' explanation, most of the time, the mentors used mother tongue rather than target language in the class even for giving the simplest instructions. Similarly, as some mentors followed the course-book on a one to one basis, they started the lesson beginning from where they finished the previous lesson totally ignoring the lesson phases. Consequently, all these gave way to descriptions instead of reflections in the journals (4 students).

Lastly, the students who observed their supervisors' heavy workload at the department expressed their astonishment when they discovered that the supervisors actually read all those journals. Thus, some confessed that they did not at all expect such a thing and thus, did not care much about how they wrote them (4 students).

\section{Conclusions}

Considering the findings of the study, we may conclude that ELT student teachers wrote their journals in a descriptive tone rather than in a reflective manner. The majority of the reflective statements used were in technical level followed by contextual level. In the journals, reflections in dialectical level are the rarest as compared to technical and contextual levels.

In addition, the findings reveal that the student teachers wrote at dialectical level on topics which they had accumulated practical experiences at the department. To elaborate, the first observation task was "the lesson" and the student teachers produced more descriptions on the lesson than reflections they observed at the practice school. Regarding the levels, we find that they reflected on the lesson they observed only at technical and contextual levels. Similarly, for the second observation task, that is the classroom management of the mentor, they produced only descriptions and technical level reflections. However, in the journals they wrote for the following two tasks namely, "the context and the language" and "blackboard use and error correction" the student teachers were able to reflect at dialectical level. This result may have stemmed from the fact that the student teachers at the ELT department do not have the opportunity to conduct one whole lesson in a real classroom setting until they start practicum. The situation deprives the students of hands on teaching experience if we put aside the micro teaching sessions where they conduct 10-15 minute lessons in their own classroom context with their peers pretending to be the intended imaginary audience. Thence, they neither have practical experience for designing and conducting a 45-minute lesson nor have they had to manage a class with real students. As a matter of fact, these short sessions do lead to positive consequences in initial English language teacher education programs (Farrell, 2008). However, because they are not conducted in a real environment, the student teachers enter practice schools lacking genuine teaching experience. On the other hand, as briefly mentioned above, we find that the student teachers were able to reflect on the teaching context and the language used in the classroom in a more sophisticated manner not only producing descriptions but also reflection at all levels. These are the topics that are often referred to and specifically emphasized and practiced during the micro teaching sessions. In parallel with these findings, due to similar reasons as above, student teachers produced reflective sentences at all levels on mentor's blackboard use and error correction strategies. Similarly, these are the issues they frequently discussed in the micro teaching 
sessions. It appears that the discussions held after each micro teaching session add to their pedagogical content knowledge (Schulman, 1986). The study findings additionally uncover that via reflective practices, if implemented on the grounds of a commonly shared understanding by all parties and on the basis of a meaningful and real life like context, teacher candidates benefit from the experience in a way to develop professionally. Thus, we may suggest that reflection should not be ignored but carefully structured and implemented in the ELT teacher education programs.

As a matter of fact, with the post methods era teachers have shown that they do not want to be restricted by the techniques of methods of teaching and thus reflective practices have gained more value. However, we should bear in mind that reflection may not meet its expected outcomes in all contexts and thus should not be used in teacher education programs just for the sake of incorporating reflection within the activities. Idealism should leave its place to realism and the definition should be made clear to all involved parties. To sum up, it is good to reflect but reflection itself also requires reflection (Akbari, 2004 p.205) and we need to question reflective practice from a multifaceted perspective. Does reflection embody professional artistry, encourage critical self-aware evaluation and embrace transformation and change? Or is reflective practice bland and mechanical with practitioners disinclined to ask awkward questions? How should models of reflection be used and in what context? We need to continue to reflect critically on these questions. Then, reflective practice will fulfill its potential to help us "make sense of the uncertainty in our workplaces" and offer us the "courage to work competently and ethically at the edge of order and chaos" (Ghaye, 2000, in Finlay 2008, p.20).

\section{Ethics Committee Approval}

The author(s) confirm(s) that the study does not need ethics committee approval according to the research integrity rules in their country. (Date of Confirmation: June 02, 2020)

\section{References}

Akbari, R. (2007). Reflections on reflection: A critical appraisal of reflective practices in L2 teacher education. System, 35, 192-207

Beck, C. \& Kosnik, C. (2002). Components of a good practicum placement: Student teacher perceptions. Teacher Education Quarterly, Spring, 81-98.

Bowen, G. A. (2009). Document analysis as a qualitative research method. Qualitative Research Journal, 9(2), 27-40. DOI:10.3316/QRJ0902027

Boyd, E.M. \& Fales, W. A. (1983). Reflective learning: Key to learning from experience. Journal of Humanistic Psychology, 23(2), 99-117.

Dewey, J. (1933). How we think: A restatement of the relation of reflective thinking to the educative process. Boston, MA: D.C., Heath and Company.

Elo, S. \& Kyngas, H. (2008). The qualitative content analysis process. Journal of Adv. Nursing, 62, $107-115$.

Ewell, P.T. (1997). Organizing for learning. AAHE Bulletin, 50(4), 3-6.

Farrell, T. S. C. (2008). Promoting reflective practice in initial English language teacher education: 
reflective microteaching. Asian Journal of English Language Teaching, 18, 1-15.

Farrel, T.S.C. (2012). Reflecting on reflective practice: (Re)Visiting Dewey and Schön. TESOL Journal, 3(1), 7-16. DOI: 10.1002/tesj.10

Frederick L. N. \& Sadler, T. (2013). A third space for reflection by teacher educators: A heuristic for understanding orientations to and components of reflection, Reflective Practice, 14(1), 43-57. DOI: $10.1080 / 14623943.2012 .732946$

Finlay, L. (2008). Reflecting on 'reflective practice'. PBPL paper 52. A discussion paper prepared for PBPL CETL (www.open.ac.uk/pbpl. January 2008)

Hattan, N. \& Smith, D. (1995). Reflection in teacher education: Towards definition and implementation. Teaching \& Teacher Education, 11(1), 33-49.

Healey, M. \& Jenkins, A (2000) Kolb's experiential learning theory and its application in geography in higher education, Journal of Geography, 99(5), 185-195. DOI:10.1080/00221340008978967

Hopkins, d. (2005). A teacher's guide to classroom research. U.K.: Open University Press, Mc GrowHill Education.

Howard, T. (2003). Culturally relevant pedagogy: Ingredients for critical teacher reflection. Theory into Practice, 42(3), 195-202. DOI: 10.1207/s15430421tip4203_5

Larrivee, B. (2000). Transforming teaching practice: Becoming the critically reflective teacher. Reflective Practice, 1(3), 293-307.

Larrivee, B. (2008). Development of a tool to assess teachers' level of reflective practice. Reflective Practice, 9(3), 341-360. DOI: 10.1080/14623940802207451

Kurt, M. (2017). Quality in reflective thinking: elicitation and classification of reflective acts. Quality Quantity, October, 1-19. DOI: 10.1007/s11135-017-0609-1

Martin, M. (2005). Reflection in teacher education: How can it be supported? Educational Action Research, 13(4), 525-542.

Mayring, P. (2014). Qualitative content analysis. Theoretical foundation, basic procedures and software solution. Klagenfurt, Australia: Retrieved on January 3, 2020 from: www.beltz.de

Mirzahi, F., Phang, F. A. \& Kashefi, H. (2014). Measuring teachers reflective thinking skills Procedia - Social and Behavioral Sciences, 141, 640 - 647.

Schulman, L. (1986). Those who understand: Knowledge growth in teaching. Educational Researcher, 15(2), 4-14.

Taggart, L. G., \& Wilson, P.W., (2005). Promoting reflective thinking in teachers: 50 action strategies. USA: Corwin Press.

Vos, H. (2001). Metacognition in Higher Education (Unpublished doctoral dissertation). University of Twente, Enschede, The Netherlands. 
Yuan, R. \& Lee, I. (2014). Pre-service teachers' changing beliefs in the teaching practicum: Three cases in an EFL context. System, 44, 1-12.

\title{
Yansıtıcı düşünce mi yoksa betimleme mi: İngilizce öğretmen adaylarının yansitıcı metinleri üzerinde bir doküman analizi
}

\begin{abstract}
Öz
Bu doküman analizi bir Türk üniversitesinde eğitim gören 59 İngilizce öğretmeni adayının uygulama okullarındaki deneyimlerine dair yansıtıcı raporlarını incelemektedir. Bu programda uygulama dönemi sırasında her aday öğretmenin önceden belirlenmiş konularda dört ayrı gözlem yaparak yansıtıcı raporlar yazması istenmektedir. Bu raporların konuları uygulama okulu öğretmeninin sınıf yönetim stratejileri, sınıf ortamı ve sınıf dili, tahta kullanımı ve hata düzeltme yöntemleridir. Bu çalışmada Hattan ve Smith'in (1995) yansitıcı yazma stilleri temelinde incelenmiş ve Taggart and Wilson (2005)'in yansıtıcı düşünce modelleri ile kategorilere ayrılmıştır. Analiz sonuçları öğrencilerin raporlarını yansıtıcı düşünceden çok betimleyici bir yaklaşımla yazdıklarını göstermektedir. Yansıtıcı düşünce modelleri bağlamında ise öğrenciler raporlarında çokluk sırasıyla teknik, bağlamsal ve diyalektik düzeylerde düşünce yapıları kullanmışlardır. Çalışmaya derinlik katmak amacıyla ayrıca on bir gönüllü öğrenci ile yüz yüze görüşmeler yapılmış ve sonuçlar tartışılmıştır. Bu görüşmelerde öğrencilerin yansitıcı düşüncenin anlamını tam olarak kavramamış olmaları, zaman azlığı, motivasyon düşüklüğü, verilen gözlem görevlerinin doğası ve danışmanların bu raporları okuyacaklarına dair inanç eksikliği raporların derin düşünülmeden yazılmalarına sebepler olarak ortaya çıkmıştır.
\end{abstract}

Anahtar sözcükler: Yansıtıcı düşünce; İngilizce öğretmen eğitimi; doküman analizi; yansıtıcı raporlar

\section{AUTHOR BIODATA}

Gülden İlin is an Associate Professor in Çukurova University, Faculty of Education, English Language Teaching Department. She offers methodology courses at undergraduate level in her department. Her major research interests are teacher cognition, action research, teacher thinking studies, professional development and perceptional change of language teachers/candidates which she also teaches at M.A. and PhD. 